$\underline{\text { Research Article }}$

\title{
In Vitro Test on the Effectiveness of Citrus limon and Allium sativum as Pediculicides
}

\section{Uji Efektivitas Citrus limon dan Allium sativum sebagai Pedikulisida secara In Vitro}

\author{
Elva Susanty', Suri Dwi Lesmana ${ }^{1}$, Dedi Afandi ${ }^{2}$, Ragil Yulianto ${ }^{3}$, Kevin Rovi Andhika ${ }^{3}$ \\ ${ }^{1}$ Department of Parasitology Faculty of Medicine Universitas Riau Pekanbaru \\ ${ }^{2}$ Department Forensic Medicine and Medicolegal Studies Faculty of Medicine Universitas Riau Pekanbaru \\ ${ }^{3}$ Medical Study Program Faculty of Medicine Faculty of Medicine Universitas Riau Pekanbaru
}

\begin{abstract}
Excessive usage of synthetic pediculicides, such as permethrin, lindane, and malathion, can induce resistance, environmental pollution, health problems, and even death. Efforts to prevent the side-effects of synthetic pediculicides are needed, one of which is by shifting to powerful yet safe natural pediculicides, such as Citrus limon (lemon) and Allium sativum (garlic). This study aimed to observe the effective concentration of Citrus limon and Allium sativum in vitro on the mortality of Pediculus humanus capitis (P. h. capitis). This research was an experimental laboratory study conducted in July to September 2019 in the Laboratory of Parasitology at Faculty of Medicine, University of Riau, while the making of Allium sativum extract was done at the Faculty of Mathematics and Science, University of Riau. A total of 288 samples of adult P. $h$. capitis was taken from children in two orphanages in Pekanbaru. Citrus limon juice and Allium sativum extract of 25\%, 50\%, $75 \%$, and $100 \%$ concentrations, permethrin $1 \%$ as the positive control, and distilled water as the negative control were used in this study, and repetition was done three times. P. h. capitis mortality was observed every 10 - 120 minutes, characterized by the absence of movement of the legs and antenna. Data analysis was performed after 120 minutes with the one-way ANOVA test, LSD (=0.05), and Lethal Concentration 50 test (LC50). The one-way ANOVA test results of this study showed that statistically Citrus limon juice and Allium sativum extracts showed differences in each treatment formulation of juice on P. h. capitis mortality (Sig 0.017<0.05 and Sig 0.000<0.05) and LC50 juice of Citrus limon and Allium sativum extract by $51.999 \%$ and $72.426 \%$. In this study, Citrus limon juice and Allium sativum extract had effect as pediculicides.
\end{abstract}

Keywords: Allium sativum, Citrus limon, Pediculicide

\begin{abstract}
ABSTRAK
Pemakaian pedikulisida sintetik secara berlebihan seperti permethrin, lindane, malathion dan lain-lain, dapat menimbulkan resistensi, pencemaran lingkungan, gangguan kesehatan bahkan kematian. Upaya pencegahan akibat efek samping pedikulisida sintetik sangat dibutuhkan, salah satunya dengan pedikulisida alami yang ampuh dan aman seperti Citrus limon (lemon) dan Allium sativum (bawang putih). Penelitian ini bertujuan untuk menguji efektivitas Citrus limon dan Allium sativum secara in vitro terhadap mortalitas Pediculus humanus capitis (P.h.capitis). Penelitian ini merupakan penelitian eksperimental laboratorium yang dilaksanakan pada bulan Juli-September tahun 2019 di Laboratorium Parasitologi Fakultas Kedokteran Universitas Riau dan pembuatan ekstrak Allium sativum di FMIPA Universitas Riau. Sebanyak 288 Sampel P.h. capitis dewasa diambil dari anak-anak di dua panti asuhan di Kota Pekanbaru. Perasan Citrus limon dan ekstrak A.sativum dengan konsentrasi 25\%, 50\%, 75\%, 100\%, permethrin 1\% sebagai kontrol positif, dan aquadest sebagai kontrol negatif digunakan dalam penelitian ini, serta dilakukan pengulangan sebanyak tiga kali. Mortalitas P.h.capitis diamati setiap 10 menit sampai 120 menit, ditandai dengan tidak adanya perpindahan/pergerakan kaki dan antena. Analisa data dilakukan setelah 120 menit dengan uji one way ANOVA, uji beda dengan $\operatorname{LSD}(=0,05)$ dan uji Lethal Concentration 50 (LC50). Hasil uji one way ANOVA penelitian ini menunjukkan bahwa secara statistik perasan Citrus limon dan ekstrak Allium sativum terdapat perbedaan tiap perlakuan formulasi perasan terhadap mortalitas $P$.h. capitis (Sig 0,017<0,05 dan Sig 0,000<0,05) dan LC50 perasan Citrus limon dan ektsrak Allium sativum sebesar 51,999\% dan 72,426\%. Pada penelitian ini Perasan Citrus limon dan ekstrak Allium sativum memiliki efek sebagai pedikulisida.
\end{abstract}

Kata Kunci: Allium sativum, Citrus limon, Pedikulisida

Correspondence: Elva Susanty. Department of Parasitology Faculty of Medicine Universitas Riau Pekanbaru, Kampus Bina Widya KM. 12,5, Simpang Baru, Kec. Tampan, Kota Pekanbaru, Riau 28293 Tel. 085262991961 Email: kaylaelva007@gmail.com 


\section{INTRODUCTION}

Pediculus humanus capitis (P. h. capitis) is head louse that causes infection in the scalp or head hair called pediculosis capitis (1). This disease is one of the health problems in the world, both developed countries such as the United States and developing countries such as Indonesia (2). Millions of capitis pediculosis cases per year occur throughout the world. Cases of capitis pediculosis in the United States are recorded to 6-12 million per year (3), whereas there is no exact number of capitis pediculosis patients in Indonesia (1).

Diseases caused by insects such as Pediculosis capitis have several treatment methods, one of which is by using insecticide (4). Insecticides made from synthetic chemicals to overcome capitis pediculosis are called chemical pediculicides such as permethrin, lindane, and malathion (5). Insecticide resistance, environmental pollution, poisoning other insects, health problems, and even death are the side effects of using chemical insecticides if used excessively (4). Side-effects caused by lindane that have been reported are skin irritation, numbness, dizziness, headache, diarrhea, nausea and vomiting, respiratory problems, seizures, and death, while, permethrin which is widely used in Indonesia can cause eye irritation, ataxia, and seizures (5). The compound of Citrus limon and Allium sativum, such as flavonoids, saponins, and essential oils, are used as insecticides or pediculicides $(4,6)$. Allicin contained in $A$. sativum also has an insecticidal effect (7).

Based on the side effects caused by synthetic chemical pediculicides and the resistance that can arise, the researchers were interested in researching natural ingredients that were safer and more effective as pediculicides such as Citrus limon (lemon) and Allium sativum (garlic). This study aimed to determine the effectiveness of Citrus limon and Allium sativum on $P . h$. capitis mortality.

\section{METHOD}

\section{Time and Place}

This research was an experimental laboratory study conducted in July to November 2019 in the Parasitology Laboratory of the Faculty of Medicine, University of Riau, while the Allium sativum extract was made in the laboratory of the Faculty of Mathematics and Science, University of Riau. The ethical clearance of this research has been obtained from the Medical and Health Research Ethics Unit of the Faculty of Medicine, University of Riau through decree number 142/UN 19.5.1.1.8/UEPKK/2019.

\section{Collection of P.h. capitis}

The samples used in this study were 288 adult $P$.h capitis measuring 1-3 $\mathrm{mm}$ in length and having white gray to black color, triangular-shaped heads that had eyes, a pair of antennas, a suction-stick-like mouth, and three pairs of legs. Pediculus humanus capitis were taken from children in orphanages in Pekanbaru using wet lice combs and placed in a glass jar that was not tightly closed and then brought to the Parasitology Laboratory, Faculty of Medicine, University of Riau. In this study, P.h. capitis sampling at two different orphanages and the effectiveness test of Citrus limon juice and A. sativum extract were carried out at different times since at the first sampling, the number of adult P.h. capitis was not sufficient for the tests.

Preparation of Citrus limon Juice and Extract $A$. sativum
Citrus limon used were imported Citrus limon purchased at a supermarket in Pekanbaru. Citrus limon imports are more oval in shape compared to local Citrus limon. Citrus limon were squeezed using a lemon squeezer, collected in an Erlenmeyer flask with glass stopper so that the essential oil content did not evaporate quickly, and followed by filtering using cheesecloth (cloth filter). Citrus limon juice produced was considered as a $100 \%$ concentration. Citrus limon $25 \%$ concentration was made by mixing $2.5 \mathrm{ml}$ Citrus limon with $7.5 \mathrm{ml}$ distilled water, $50 \%$ concentration was made by mixing $5 \mathrm{ml}$ Citrus limon with $5 \mathrm{ml}$ distilled water, and $75 \%$ concentration was made by mixing $7.5 \mathrm{ml}$ Citrus limon with $2.5 \mathrm{ml}$ distilled water.

Allium sativum used in this research was Allium sativum locally produced in Bukit Tinggi. A. sativum extract was made using maceration. As much as $2 \mathrm{~kg}$ of cleaned garlic was sliced obtaining a thickness of $1-2 \mathrm{~mm}$ and roasted to dry for 1 hour until the color turned brown and the water content reduced. The dried garlic was then crushed using a food processor and stored in airtight plastic. A. sativum simplicia was taken as much as 500 grams, placed in a jar, and added with $70 \%$ ethanol in a ratio of 1: 5 (500gr of $A$. sativum simplicia mixed to $2500 \mathrm{ml}$ of ethanol), and then stirred until homogeneous. The solution was allowed to stand for 24 hours and filtered using filter paper, and the pulp obtained was macerated with the same solvent, $70 \%$ ethanol. This stage was carried out twice until obtaining clear filtrate. The filtrate was concentrated using a rotary evaporator at $400^{\circ} \mathrm{C}$ until a concentrated extract (solution) was obtained. In this study, A. sativum extract obtained was as much as $150 \mathrm{ml}$ and was considered as a $100 \%$ concentration. A. sativum extract of $25 \%$ concentration was made by mixing $2.5 \mathrm{ml} A$. sativum extract with $7.5 \mathrm{ml}$ distilled water, $50 \%$ concentration was made by mixing $5 \mathrm{ml}$ A. sativum extract with $5 \mathrm{ml}$ distilled water, and $75 \%$ concentration was made by mixing $7.5 \mathrm{ml}$ A. sativum extract with $2.5 \mathrm{ml}$ distilled water.

\section{Treatment and Statistical Analysis}

Six petri dishes were used for the formula of $100 \%$ concentration, $75 \%$ concentration, $50 \%$ concentration, and $25 \%$ concentration, permethrin $1 \%$ was used as the positive control, and distilled water was used as the negative control. Whatman No. 1 filter paper was cut following the size of the petri dish used and put in the base of a petri dish. The effectiveness test of Citrus limon formula and $A$. sativum extract was performed three times.

The test for the Citrus limon was a modification from Suprobowati and Suliati (8) and Shrivastava, et al. (9). A number of ten P.h. capitis were put in each petri dish of Citrus limon juice extract formula, followed by dripping 2.5 $\mathrm{ml}$ of Citrus limon juice extract concentration of $100 \%$, $75 \%, 50 \%$, $25 \%$, permethrin $1 \%$, and distilled water, respectively. P.h. capitis mortality was observed macroscopically every 10-120 minutes, characterized by the absence of movement in the foot/antenna of P.h. capitis.

The test of Allium sativum extract was based from Tigauw, et al. (10). A number of six P.h. capitis were put in each petri dish of $A$. sativum extract formula, followed by dripping $2.5 \mathrm{ml}$ of $A$. sativum extract concentration of $100 \%, 75 \%$, $50 \%, 25 \%$, permethrin $1 \%$, and distilled water, respectively. P.h. capitis mortality was observed macroscopically every 10-120 minutes, characterized by the absence of movement in the foot/antenna P.h. capitis. 
Table 1. The behavior of lemon citrus juice on P. $h$. Capitis mortality

\begin{tabular}{|c|c|c|c|c|c|c|c|c|c|c|c|c|}
\hline \multirow[b]{2}{*}{ Concentration } & \multicolumn{12}{|c|}{ Mean of $P$. h. capitis Mortality (\%) Time Series in Minutes } \\
\hline & $\begin{array}{c}10 \\
\text { Minutes }\end{array}$ & $\begin{array}{c}20 \\
\text { Minutes }\end{array}$ & $\begin{array}{c}30 \\
\text { Minutes }\end{array}$ & $\begin{array}{c}40 \\
\text { Minutes }\end{array}$ & $\begin{array}{c}50 \\
\text { Minutes }\end{array}$ & $\begin{array}{c}60 \\
\text { Minutes }\end{array}$ & $\begin{array}{c}70 \\
\text { Minutes }\end{array}$ & $\begin{array}{c}80 \\
\text { Minutes }\end{array}$ & $\begin{array}{c}90 \\
\text { Minutes }\end{array}$ & $\begin{array}{c}100 \\
\text { Minutes }\end{array}$ & $\begin{array}{c}110 \\
\text { Minutes }\end{array}$ & $\begin{array}{c}120 \\
\text { Minutes }\end{array}$ \\
\hline $25 \%$ & 10 & 10 & 10 & 10 & 10 & 10 & 10 & 10 & 10 & 10 & 20 & 20 \\
\hline $50 \%$ & 0 & 10 & 10 & 10 & 20 & 20 & 30 & 30 & 40 & 50 & 50 & 50 \\
\hline $75 \%$ & 10 & 10 & 10 & 10 & 10 & 20 & 30 & 30 & 40 & 40 & 50 & 50 \\
\hline $100 \%$ & 20 & 20 & 20 & 30 & 30 & 40 & 50 & 60 & 60 & 70 & 80 & 90 \\
\hline Positive control & 90 & 90 & 100 & 100 & 100 & 100 & 100 & 100 & 100 & 100 & 100 & 100 \\
\hline Negative control & 0 & 0 & 0 & 0 & 0 & 0 & 0 & 0 & 0 & 0 & 0 & 0 \\
\hline
\end{tabular}

The technique used to analyze the data was by conducting a Kolmogorov-Smirnov normality test to find out if the sample was from a normally distributed population. Data analysis was continued by using the Homogeneity of Variance test to find out whether the sample was homogeneous, followed by the one-way ANOVA test to determine the effect of Citrus lemon juice on $P$. $h$. capitis mortality, Post Hoc with LSD $(=0.05)$ and Probit test for Lethal Concentration 50 (LC50) to determine the concentration needed to kill $50 \%$ of $P$. $h$. capitis. The tests of normality, variance, differentiation, and LC 50 were performed at the $120^{\text {th }}$ minutes.

\section{RESULTS}

\section{Effectiveness Test on Citrus limon}

Data on the behavior results of lemon citrus juice with various concentrations on $P$. $h$. capitis mortality can be seen in Table 1.

Table 1 showed that the average mortality of $P$. $h$. capitis after 120 minutes with a treatment of the $25 \%$ Citrus limon concentration was $20 \%$, the $50 \%$ concentration was $50 \%$, the $75 \%$ concentration was $50 \%$, and the $100 \%$ concentration was $90 \%$. Positive control could kill all $P$. $h$. capitis in the $30^{\text {th }}$ minute, while negative control could not kill $P$. h. capitis until the $120^{\text {th }}$ minute. Results showed that the data were normally distributed $(p=0,200)$ and homogeneous $(p=0.841)$. The one-way ANOVA test results in this study indicated that statistically there were differences in each treatment of Citrus limon juice formulation on $P$. $h$. capitis mortality $(p=0.017)$. The results of LSD test in this study showed that in the effect of Citrus limon juice test material, on the mortality of $P$. $h$. capitis was found only between $25 \%$ concentration and the $100 \%$ concentration.

Table 2. Probit analysis for lethal concentration (LC)

\begin{tabular}{lccc}
\hline \multirow{2}{*}{$\begin{array}{c}\text { Lethal } \\
\text { Concentration }\end{array}$} & \multicolumn{3}{c}{ Concentration (\%) } \\
\cline { 2 - 4 } & Estimation & Lower Limit & Upper Limit \\
\hline LC50 & 51.999 & 30.836 & 76.118 \\
\hline
\end{tabular}

Based on statistics analysis, the effective concentration of Citrus limon to kill 50\% P. h. capitis (LC50) was 51.999 (\%Cl: 30.836\%-76.118\%).

\section{Allium sativum Effectiveness Test}

Data from the behavior of Allium sativum extract with various concentrations of $P$. h. capitis mortality can be seen in table 3.

Result show that the average mortality of $P$. h. capitis after 120 minutes by the administration of Allium sativum extract $25 \%$ concentration could not kill $P$. $h$. capitis, the $50 \%$ concentration by $15 \%$, the $50 \%$ concentration by $33 \%$, the $100 \%$ concentration by $83 \%$. Positive control could kill all $P$. $h$. capitis samples in the $40^{\text {th }}$ minute, while negative control could not kill $P$. $h$. capitis until the $120^{\text {th }}$ minute.

Data were normally distributed $(p=0.200)$ and homogeneous $(p=0.154)$. The one-way ANOVA test results in this study indicated that statistically, there were differences in each treatment of the Allium sativum juice formulation against $P$. $h$. capitis mortality. $(p=0.001)$. The results of LSD test in this study showed that in the test material of Allium sativum extract, there were differences in the mortality of $P . h$. capitis for the $25 \%$ concentration with the $50 \%, 75 \%$, and $100 \%$ concentrations, the $50 \%$ concentration with the $25 \%, 75 \%$, and $100 \%$ concentrations, the $75 \%$ concentration with $25 \%, 50 \%$, and $100 \%$ concentration, while $100 \%$ concentration with $25 \%, 50 \%$, and $75 \%$ concentrations.

Table 4. Probit Analysis for Lethal Concentration (LC)

\begin{tabular}{cccc}
\hline \multirow{2}{*}{$\begin{array}{c}\text { Lethal } \\
\text { Concentration }\end{array}$} & \multicolumn{3}{c}{ Concentration (\%) } \\
\cline { 2 - 4 } & Estimation & Lower Limit & Upper Limit \\
\hline LC50 & 72,426 & 61,826 & 85,792 \\
\hline
\end{tabular}

Based on statistics, the effective concentration of Allium sativum to kill $50 \%$ P. h. capitis (LC50) was $72.426 \%(\mathrm{Cl}$ : $76.118 \%-85,792 \%)$

Table 3. The behavior of Allium sativum extract on $P$. $h$. capitis mortality

\begin{tabular}{|c|c|c|c|c|c|c|c|c|c|c|c|c|}
\hline \multirow[b]{2}{*}{ Concentration } & \multicolumn{12}{|c|}{ Mean of $P . h$. capitis Mortality (\%) Time Series in Minutes } \\
\hline & $\begin{array}{c}10 \\
\text { Minutes }\end{array}$ & $\begin{array}{c}20 \\
\text { Minutes }\end{array}$ & $\begin{array}{c}30 \\
\text { Minutes }\end{array}$ & $\begin{array}{c}40 \\
\text { Minutes }\end{array}$ & $\begin{array}{c}50 \\
\text { Minutes }\end{array}$ & $\begin{array}{c}60 \\
\text { Minutes }\end{array}$ & $\begin{array}{c}70 \\
\text { Minutes }\end{array}$ & $\begin{array}{c}80 \\
\text { Minutes }\end{array}$ & $\begin{array}{c}90 \\
\text { Minutes }\end{array}$ & $\begin{array}{c}100 \\
\text { Minutes }\end{array}$ & $\begin{array}{c}110 \\
\text { Minutes }\end{array}$ & $\begin{array}{c}120 \\
\text { Minutes }\end{array}$ \\
\hline $25 \%$ & 0 & 0 & 0 & 0 & 0 & 0 & 0 & 0 & 0 & 0 & 0 & 0 \\
\hline $50 \%$ & 0 & 0 & 17 & 17 & 17 & 17 & 17 & 17 & 17 & 15 & 15 & 15 \\
\hline $75 \%$ & 0 & 0 & 0 & 0 & 0 & 0 & 17 & 17 & 33 & 33 & 33 & 33 \\
\hline $100 \%$ & 0 & 0 & 0 & 0 & 17 & 17 & 17 & 50 & 50 & 50 & 50 & 83 \\
\hline Positive control & 83 & 83 & 83 & 100 & 100 & 100 & 100 & 100 & 100 & 100 & 100 & 100 \\
\hline Negative control & 0 & 0 & 0 & 0 & 0 & 0 & 0 & 0 & 0 & 0 & 0 & 0 \\
\hline
\end{tabular}




\section{DISCUSSION}

The results of this study showed that in the $120^{\text {th }}$ minute, the $100 \%$ concentration of Citrus limon killed P. h. capitis the most $(90 \%)$. This was probably due to the concentration of $100 \%$ pure fresh Citrus limon juice without the addition of distilled water, so there were many active ingredients contained. This result was supported by Shrivastava V, et al. (7) who stated that a higher concentration of an ingredient would result more active ingredients contained and higher killing power. This study was the same as the study conducted by Suprobowati and Suliati (8) that showed at the $120^{\text {th }}$ minute, the $100 \%$ concentration of lime killed more $P$. $h$. capitis than any other concentrations. According to Nurhaifah and Sukesi (11), the high mortality rate in the larvae test carried out was due to the presence of chemical compounds in sweet oranges that played a role in the biological activities in the growth and development of larva.

The results of this study indicated that the negative control containing distilled water could not kill P. h. capitis, while the lowest concentration of Citrus limon (25\%) could kill P. h. capitis by $20 \%$. This proved that there was an effect of the administration of Citrus limon juice on $P$. h. capitis mortality. This is in line with research conducted by Nurhaifah and Sukesi (11) that stated negative control (distilled water) could not kill Aedes aegypti (A. aegypti) larvae, whereas low concentration at $0.2 \%$ of lime juice could kill $57.32 \%$ of $A$. aegypti larvae. The results of research conducted by Shrivastava, et al. (9) showed that Citrus limon could be used as a pediculicide, and Citrus limon juice without dilution or addition of distilled water could kill $95 \% 5 \%$ P. h. capitis within 3 hours. The research results conducted by El Akkad, et al. (12) showed that Citrus limon juice had a higher pediculicidal effect (100\%) compared to olive oil (96.7\%) and tea tree oil (23.3\%).

The one-way ANOVA test results in this study indicated that statistically there were differences in the behavior of Citrus limon juice formulation on P. h. capitis mortality (Sig $0.017<0.05)$. The results of LSD test in this study showed that in the Citrus limon juice test material, there was a difference in the mortality of $P$. $h$. capitis for the $25 \%$ concentration with the $100 \%$ concentration, and the $100 \%$ concentration with the concentrations of $25 \%, 50 \%$, and $75 \%$. The difference in Citrus limon juice extraction might be due to differences in the amount of active ingredients contained. The results of this study also showed that based on statistics effective concentration of Citrus limon to kill 50\% P. h. capitis (LC50) was 51.999\%.

Various types of plants have been known to contain bioactive compounds such as phenylpropane, terpenoids, alkaloids, acerogenins, steroids, and tannins that are insecticides (11). Some of the contents of Citrus limon are vitamin C, citric acid, essential oils, bioflavonoids, polyphenols, coumarin, flavonoids, and volatile oils on the skin such as limonents ( $\pm 70 \%), \alpha$-terpinenes, $\alpha$-pinen, $\beta$ pinen, coumarin, and polyphenols (6). Citrus limon can be used as a pediculicide because it contains flavonoids and essential oils (5). Flavonoids are phenol compounds that are water-soluble and can be used as active ingredients for insecticides (4). Flavonoid metabolites such as isoflavones, biochanin, and pinocembrin have toxic effects on insects $(4,13)$. Isoflavone has a toxic effect on insects by influencing the behavior, growth, and development of insects (14). Rotenone is a type of isoflavone as a mitochondrial poison by blocking the electron transport chain leading to inhibition of energy production (15). Insect fertility can be reduced by the presence of biochanin metabolite compounds (13), pinocembrin and limonoid metabolite compounds contain antifeedant that reduces the appetite of insects and prevents insects from digesting food so that their stomachs are disturbed $(11,13)$.

The results of this study indicated that the formula of pediculicide Allium sativum with $100 \%$ concentration is significantly the most effective in killing $P$. $h$. capitis in vitro (83\%). The one-way ANOVA test results in this study indicated that statistically there were differences in each treatment of the Allium sativum juice formulation against $P$. h. capitis mortality (Sig $0.000<0.05)$. The results of LSD test in this study showed that in the Allium sativum juice test material, there were differences in the mortality of $P$. $h$. capitis in the $25 \%$ concentration of with the concentrations of $50 \%, 75 \%$, and $100 \%$, the $50 \%$ concentration with the concentrations of $25 \%, 75 \%$, and $100 \%$, the $75 \%$ concentration with the concentrations of $25 \%, 50 \%, 100 \%$, and the $100 \%$ concentration with the concentrations of $25 \%, 50 \%$, and $75 \%$.

The results of this study indicate that Allium sativum can be used as a pediculicide. This is supported by the research results by Meriga, et al. (16) that stated Allium sativum had a pediculicidal effect. The results of this study were the same as the study conducted by Pritacindy, et al. (17) that stated there were differences in the effectiveness of Allium sativum extracts based on Allium sativum concentration, and the higher the concentration level, the faster the $P$. $h$. capitis killing time. The number of active compounds that have direct contact with $P$. h. capitis causes $P$. h . capitis mortality at various concentrations (4). The results of the study conducted by Rusdy (7) with Allium sativum extract concentrations of $5 \%, 10 \%, 15 \%$, and $20 \%$ in the golden snail pest showed that the golden snail's dead speed was dominated by the high concentration level (20\%). It means that concentrations of active ingredients that were highly concentrated, such as diallyl sulfide contained in Allium sativum, were more effective for controlling snails. The results of this study were also the same as the study by Sasmilati (4) that reported based on the results of the oneway ANOVA test there were significant differences in the effects of larvicides in the different concentrations of Allium sativum solution groups with $p$-value $<0.05$ ( $\mathrm{sig}$ ) and found significant differences between groups that was $\mathrm{p}$-value $<0.05$ (sig). The results of a study conducted by Pritacindy, et al. (17) showed that Allium sativum proved to be effective as a pediculicide, and a higher concentration of $A$. sativum extract would be a more effective insecticide for hair lice. The results of research conducted by Al-Zanbagi and Al-Hasdi (18) showed that $A$. sativum was a strong natural pediculicide, medicinally substance with no toxicity; further, the results also proved that higher concentrations of Allium sativum would kill P.h.capitis more effectively.

Allium sativum contains metabolite compounds such as allicin, adenosine, ajoene, flavonoids, saponins, tuberholosides, scordinin $(10,17)$, alliin, scordinin, methylene trisulfide, saltivine, essential oils (4). Sulfide derivatives, namely allicin, are stomach poisons that kill the target organism if allicin enters the digestive organs and is absorbed by the intestinal wall (7). Allicin is produced from alliin and alliinase enzymes formed after the processing of Allium sativum, and it is very reactive and unstable (19). This instability causes allicin to turn into a compound of allyl disulfide, which is classified as an 
organic synthetic pesticide $(7,19)$ and inhibits or blocks the action of the cholinesterase and ganglion enzymes in the central nervous system terminal (7).

The production of RNA and lipids is also associated with allicin, that is when the production of RNA in small amounts or not produced, the protein synthesis is reduced and results in the cessation of each phase because there is no or a little RNA messenger, ribosomal (20). Proteins and amino acids are not produced that will interfere with the growth and development of insects (16). Research by Nejad, et al. (20) on the growth of Staphylococcus aureus on hamburgers added with $3 \mathrm{ml}$ garlic seasoning and stored for three months showed less amount of Staphylococcus aureus compared with those added with 1 $\mathrm{ml}$ and $2 \mathrm{ml}$ of garlic. This was because allicin contained in Allium sativum entered the bacteria through the lipid membrane and inhibits RNA synthesis.

Flavonoids contained in Citrus limon and Allium sativum work as respiratory inhibitors (13). Flavonoids enter the insect's body through the respiratory system, namely spiracles that can be found on the surface of the body so that paralyze the nerve and damage the spiracles, and it causes the insects not be able to breathe and eventually die (21). Disruption of energy metabolism in the mitochondria caused by flavonoids by inhibiting the electron transport system blocks the ATP production and causes a decrease in oxygen consumption by the mitochondria (4). Other metabolite compounds contained in Citrus limon and Allium sativum, saponins, enter through the walls of the insect's body and are toxic, which results in the death of the insects (21).

Essential oils contained in Citrus limon and Allium sativum plants are 1,3-Dithiane, di-2-propenyl, 1-Propene, 3,3'thiobis, methyl 2-propenyl, 3-vinyl-1,3- dithiin, 2-vinyl1,3-dithiin, di-2- propenyl, 3-vinyl-1,2 dithiin1-chloro-4(1-ethoxy) -2-methylbut-2-ene, methyl 2-propenyl, diallyl disulfide, 3-vinyl-1,2 dithiin, methyl1-methyl-2-butenyl sulphide, octane 4-bromine (7), which have effectiveness as insecticides, atypic microbes, and anti parasites (22). Essential oils have biological activity against insects that are repellent, attractive, contact poisons, respiratory toxins, reducing appetite, inhibiting egg-laying, inhibiting growth, and reducing fertility (5). Direct or indirect effects of essential oils through absorption in the cuticles make essential oils effective pediculicides (23).

Phytochemical test results showed that essential oils contain secondary metabolites in the form of alkaloids, terpenoids, and tannins (4). Toxic alkaloids and nerve poisons are alkalic substances and contain one or more nitrogen atoms (24). The research results conducted by

\section{REFERENCES}

1. Hapsari Al. Personal Hygiene Rambut terhadap Pedikulosis Kapitis Berdasarkan Karateristik Demografinya. Seminar Nasional Biologi, IPA dan Pembelajarannya I. Jurnal Unmuh Jember. 2017; 110-121.

2. Mayasin RM and Norsiah W. Pediculosis Capitis dan Personal Hygiene pada Anak SD di Daerah Pedesaan Kotamadya Banjarbaru. Medical Laboratory Technology Journal. 2017; 3(2): 58-62.

3. Anggraini A, Anum $Q$, and Masri M. Hubungan Tingkat Pengetahuan dan Personal Hygiene
Samilati, et al. (4) showed that the death of mosquito larvae given Allium sativum solution was through four phases, namely stimulation (changes in larval behavior from normal circumstances), convulsions, paralysis, and ended with death. Another secondary metabolite contained in essential oils is terpenoids, which have a very low molecular weight so that they can act mechanically by penetrating the cuticle of $P$. $h$. capitis up to the trachea so that they are suffocated due to the inability to breathe (23). Terpenoids do not eradicate but are antifeedant or reduce the digestive enzymes (21) and the appetite in larvae because these terpenoids have a bitter and sharp taste, which causes larvae not to eat, so they starve and die (25). Tannins found in Citrus limon and Allium sativum are toxic, have a bitter taste, and have an antifeedant effect (23). Tannins play a role in disrupting the process of absorption of proteins needed for growth by binding to proteins in the digestive system of insects (24).

Essential oils are effective pediculicides due to their direct effects through absorption in the cuticles and indirect absorption through oil vapor (23). This causes the essential oil to have better contact against $P . h$. capitis than permethrin because direct absorption of permethrin is only through the cuticle (5). Differences in the number of $P . h$. capitis deaths in this study might have been caused by differences in the sensitivity of $P$. $h$. capitis. Some conditions that affected the differences of number of died insects from each concentration were differences in the insect sensitivity to the solution concentrations, the condition of each insect when test materials were given and when samples were taken, the environmental conditions such as the temperature at which experiment was conducted, extract storage $(4,25)$, the extract quality (test material) which was affected by plant species, plant age, parts used, and etc. (19) The results of research conducted by Alzowahi, et al. (25) showed that there were differences in the ability of Allium sativum as an antibacterial that were stored at $4^{\circ} \mathrm{C}$ and room temperature of $30^{\circ} \mathrm{C}$. The essential oil will evaporate and will be followed by an oxidation process that affects the quality if it is placed uncovered during the storage process (19).

Based on the results of this study, it can be concluded that Citrus limon and Allium sativum have pediculicides effect and kill 50\% P. h. capitis (LC50) at a concentration 51.999\% for Citrus limon and $72.426 \%$ for Allium sativum.

\section{ACKNOWLEDGMENT}

The researchers would like to thank the Faculty of Medicine Universitas Riau for funding this research.

terhadap Kejadian Pedikulosis Kapitis pada Anak Asuh di Panti Asuhan Liga Dakwah Sumatera Barat. Jurnal Kesehatan Andalas. 2016; 7(1): 131-136.

4. Sasmilati U, Pratiwi AD, and Saktiansyah LOA. Efektivitas Larutan Bawang Putih (Allium Sativum Linn) sebagai Larvasida terhadap Kematian Larva Aedes Aegypti di Kota Kendari Tahun 2016. Jurnal IImiah Mahasisa Kesehatan Masyarakat Unsyiah. 2017; 2(6): 1-7.

5. Arrizqiyani T, Khusnul, and Virgianti DP. Uji Efektivitas Formula Pedikulosida Berbahan Aktif Minyak Atsiri terhadap Mortalitas Kutu Kepala (Pediculus 
Humanus Capitis De Geer) secara In Vitro. The Journal of Muhammadiyah Medical Laboratory Technologist. 2018; 2(1): 1-11.

6. Suprobowati OD and Suliati. Efek Perasan Jeruk Nipis (Citrus aurantifolia) terhadap Mortalitas Kutu Kepala. Proceeding Seminar Nasional Kesehatan Tahun 2016. Politeknik Kesehatan Kemenkes Surabaya. Surabaya, November 26, 2016: p. 86-89.

7. Shrivastava V, Purwal L, and Jain UK. In Vitro Pediculicidal Activity of Juice of Citrus Limon. International Journal of PharmTech Research. 2010; 2(3): 1792-1795.

8. Tigauw SMI, Salaki CL, and Manueke DJ. Efektivitas Ekstrak Bawag Putih dan Tembakau terhadap Kutu Daun (Myzus Persicae Sulz.) pada Tanaman Cabai (Capsicum Sp.). Eugenia. 2015; 21(3): 135-141.

9. Rusdy A. Pengaruh Pemberian Ekstrak Bawang Putih terhadap Mortalitas Keong Emas. Jurnal Floratek. 2010; 5(2): 172-180.

10. Nurhaifah D and Sukesi TW. Efektivitas Air Perasan Kulit Jeruk Manis sebagai Larvasida Nyamuk Aedes Aegypti. Kesmas: National Public Health Journal. 2015; 9(3): 207-212.

11. El Akkad DMH, El-Gebaly NSM, Yousof HASA, and Ismail MAM. Electron Microscopic Alterations in Pediculus Humanus Capitis Exposed to Some Pediculicidal Plant Extracts. The Korean Journal of Parasitology. 2016; 54(4): 527-532.

12. Chaturvedi D, Suhane R, and Shrivastava RR. Basketful Benefit of Citrus limon. International Research Journal of Pharmacy. 2016; 7(6): 1-4.

13. Nukmal N, Rosa E, Apriliyani AS, and Kanedi M. Insecticidal Effects of the Flavonoid-Rich Fraction of Leaves Extract of Gamal (Gliricidia Sepium) on the Coffee Mealybugs (Planococcus Citri Risso.). Annual Research and Review in Biology. 2017; 16(6): 1-9.

14. Hikal WM, Baeshen RS, and Said-Al Ahl HAH. Botanical Insecticide as Simple Extractives for Pest Control. Cogent Biology. 2017; 3: 1-16.

15. Zibaee A. Botanical Insecticides and Their Effects on Insect Biochemistry and Immunity, Pesticides in the Modern World - Pests Control and Pesticides Exposure and Toxicity Assessment. (Onlne) 2011. http://www.intechopen.com/books/pesticides-inthe-modern-world-pests-control-and-pesticidesexposure-and- toxicity-assessment/botanicalinsecticides-and-their-effects-on-insectbiochemistry-and-immunity [accessed 2020
January 28].

16. Meriga B, Mopuri R, and MuraliKrishna T. Insecticidal, Antimicrobial and Antioxidant Activities of Bulb Extracts of Allium Sativum. Asian Pacific Journal of Tropical Medicine. 2012; 5(5): 391-395.

17. Pritacindy AP, Supriyadi, and Kurniawan A. Uji Efektifitas Ekstrak Bawang Putih (Allium Sativum) sebagai Insektisida terhadap Kutu Rambut (Pediculus Capitis). Preventia The Indonesian Journal of Public Health. 2017; 2(1): 1-9.

18. Al-Zanbagi $\mathrm{N}$ and $\mathrm{Al}$-Hashdi DF. In Vitro Investigation of Allium Sativum as Anti-Head Lice in Jeddah, Saudi Arabia. International Journal of Scientific Research. 2016; 5(5): 632-635.

19. Prastiwi R, Siska, and Marlita N. Parameter Fisikokimiad dan Analisis Kadar Allyl Disulfide dalam Ekstrak Etanol 70\% Bawang Putih (Allium Sativum L.) dengan Perbandingan Daerah Tempat Tumbuh. Pharmaceutical Sciences and Research. 2017; 4(1): 32-47.

20. Nejad ASM, Shabani S, Bayat M, and Hosseini SE. Antibacterial Effect of Garlic Aqueous Extract on Staphylococcus Aureus in Hamburger. Jundishapur Journal of Microbiology. 2014; 7(11): 1-5.

21. Darmadi, Pradhasumitra D, and Setiawan SE. Efektifitas Ekstrak Kulit Duku (Lansium domesticum corr) terhadap Mortalitas Pedikulus Humanus Capitis sebagai Penyebab Pedikulosis pada Anak. Journal of Pharmacy and Science. 2018; 1(2): 10-19.

22. Di Campli E, Di Bartolomeo S, Pizzi PD, et al. Activity of Tea Tree Oil and Nerolidol Alone or in Combination Against Pediculus Capitis (Head Lice) and Its Eggs. Parasitology Research. 2012; 111(5): 1985-1992.

23. Bauri RK, Tigga MN, and Kullu SS. A Review on Use of Medicinal Plants to Control Parasites. Indian Journal of Natural Products and Resources. 2015; 6(4): 268-277.

24. Hasyim A, Setiawati W, Lukman L, and Marhaeni LS. Evaluasi Konsentrasi Lethal dan Waktu Lethal Insektisida Botani terhadap Ulat Bawang ( Spodoptera Exigua ) di Laboratorium. Jurnal Holtikutura. 2019; 9(1):69-80.

25. Alzowahi FAM, Abu-taleb A, As-Suhbani A, and Kadam TA. The Inhibitory Effects of Garlic Extract and Its Fractions Against Some Enterobacteriaceae sp Isolated from Sprouted Mung Bean. International Journal of Current Microbiology and Applied Sciences. 2013; 2(7): 104-115. 